\title{
Pemberdayaan Masyarakat Desa Terhadap Prospek Unggulan Jambu Gondangmanis Menjadi Desa Wisata (di Desa Gondangmanis, Kec. Bandar Kedung Mulyo, Kab. Jombang)
}

\author{
Eny Dyah Yuniwati ${ }^{1}$, M. Dullah ${ }^{2}$, M Cholil $^{3}$, Yulianita Verlandes ${ }^{4}$ \\ Universitas Wisnuwardhana Malang ${ }^{1,2,}$ Universitas Darul Umum ${ }^{3}$ Universitas Pesantren Darul Ulum ${ }^{4}$ \\ nieyuniwati@gmail.com ${ }^{1}$, dulanoh@gmail.com ${ }^{2}$, cholel.samper@gmail.com ${ }^{3}$, ynitaverlandes@gmail.com ${ }^{4}$
}

\begin{abstract}
Gondangmanis guava production decreases every year, this is caused by pests and plant diseases, due to decreased soil quality, and soil fertility. In addition there are no good cultivation techniques so that Gondangmanis guava only grows conventionally. The purpose of this activity, for assistance, training and development of Gondangmanis guava picking tourism village. Implementation activities begin from April 2019 until August 2019, in Gondangmanis Village, kec. Bandar kedungmulyo, Jombang. The method used is a demonstration plot, and in-depth interviews. From the results of the assistance in this 3rd year, it can be concluded that there has been assistance, training and cultivation of Gondangmanis guava production. Community participation, especially those involved in guava development activities, and utilization of livestock waste is very high. Likewise, support from community leaders and village and district level officials was very supportive. Also pioneered the formation of tourism Gondangmanis guava village. The Guava Gondangmanis Community Group and the Tourism Awareness Group (POKDARWIS) have been formed. The role of the Department of Agriculture and Animal Husbandry and the Regional Government of Bappeda in Jombang Regency is also very high, because during the preparation and coordination process, it always receives attention from the leadership of the Regional Government, as evidenced by the formation of leading tourism in Jombang.
\end{abstract}

Keywords: Community Empowerment; Excellent Prospects; Guava Gondangmanis;

Tourism Village.

\begin{abstract}
Abstrak
Produksi jambu gondangmanis setiap tahunnya mengalami penurunan, hal ini disebabkan serangan hama dan penyakit tanaman, akibat menurunnya kualitas lahan, dan kesuburan tanahnya. Selain itu belum adanya teknik budidaya yang baik sehingga jambu Gondangmanis hanya tumbuh secata konvensional saja. Tujuan dari kegiatan ini, untuk program pendampingan, pelatihan dan pengembangan jambu Gondangmanis menjadi desa wisata petik jambu. Pelaksanaan Kegiatan dimulai April 2019 sampai Agustus 2019, di Desa Gondangmanis, kec. Bandar kedungmulyo, Jombang.Metode yang di gunakan adalah demplot budidaya, dan indept interview. Hasil pendampingan di tahun ke 3 ini, dapat disimpulkan bahwa telah di lakukan pendampingan, pelatihan dan budidaya produksi jambu Gondangmanis.Partisipasi masyarakat, khususnya yang terlibat dalam kegiatan pengembangan jambu, dan pemanfaatan limbah ternak sangat tinggi. Demikian pula dukungan dari tokoh masyarakat dan perangkat desa serta tingkat kecamatan
\end{abstract}


sangat mendukung. Juga telah di rintis terbentuknya wisata kampung jambu Gondangmanis.Telah terbentuk kelompok Masyarakat jambu Gondangmanis dan Kelompok Sadar Wisata (POKDARWIS). Peran Dinas Pertanian dan Peternakan juga Bappeda Pemerintah Daerah Kabupaten Jombang juga sangat tinggi, karena selama proses persiapan dan koordinasi selalu mendapat perhatian dari pimpinan Pemda, terbukti dengan terbentuknya wisata unggulan jombang.

Kata Kunci: Pemberdayaan Masyarakat; Prospek Unggulan; Jambu Gondangmanis; Desa Wisata.

\section{A. PEndahuluan}

Salah satu varietas jambu yang telah menjadi varietas unggul nasional yang mulai dikenal dan pangsa pasarnya tinggi di swalayan yaitu jambu Gondang Manis dari kabupaten Jombang. Jambu Gondangmanis ini merupakan produk unggulan Jombang karena memiliki potensi antara lain nilai ekonomis cukup tinggi serta warna buah yang sangat menarik (ungu kehitaman jika buah telah tua dan merah muda keunguan jika buah masih muda), bentuk dan ukuran buah sedang, rasa buah segar, warna daging buah putih bersih dan tekstur dalam buah lunak seperti diselimuti kapas sertaa aroma buah yang harum. Konsumen sangat menyukai rasa segar sedikit asam, daging buah tebal dan kenyal serta penampilan jambu bol yang khas.(E.D. Yuniwati, 2017).

Potensi jambu Gondang Manis terletak pada kualitas buah yang unggul, produksi tinggi serta nilai ekonomis yang tinggi. Pohon jambu gondangmanis yang baru pertama kali berbuah asal dari biji (umur 2 tahun) dapat menghasilkan buah sebanyak 40-50 kg , pada umur 4 tahun menghasilkan 100-200 kg /pohon/tahun, jika pohon jambu berumur di atas 10 th, menghasilkan 300-400 $\mathrm{kw} /$ pohon/tahun dengan dua kali musim panen. Bila rata-rata tanaman jambu menghasilkan $200 \mathrm{~kg} /$ pohon dan harga buah jambu pada tahun 2016 sekitar Rp 10.000,-Rp 17.000,- per kilogram di tingkat petani maka satu tanaman dapat menghasilkan sekitar Rp 2.000.000,- hingga Rp 3.400.000,.

Produksi jambu gondangmanis setiap tahunnya mengalami penurunan, hal ini dikarenakan serangan hama dan penyakit tanaman akibat menurunnya kualitas lahan, baik karena kesuburan tanahnya maupun belum adanya teknik budidaya yang di terapkan pada tanaman jambu Gondangmanis. Hal ini di akibatkan oleh beberapa faktor antara lain : penyediaan input produksi pertanian yang kurang, belum adanya pengembangan teknologi budidaya jambu, belum adanya perakitan teknologi pasca panen jambu, dan tidak adanya pemasaran produksi jambu yang lebih luas. (Suhadi, 2019).

Hasil dari Social Mapping yang di lakukan di 3 Dusun, permasalahan yang di hadapi adalah Penurunan produktifitas, lingkungan dan ekosistem lahan pada budidaya jambu gondangmanis menurun, penyebaran penyakit penggerek batang pada pohon jambu Gondangmanis tinggi, kurangnya perhatian pemerintah daerah, tidak adanya penyuluhan pemeliharaan jambu gondangmanis, kurangnya pembibitan jambu (Eny Dyah Yuniwati, 2017).

Tabel 1. di sajikan data petani jambu, Desa gondangmanis, Kec.Bandarkedung Mulyo, kabupaten

\begin{tabular}{ccccc}
\multicolumn{5}{c}{ Jombang } \\
\hline No & Uraian & $\begin{array}{c}\text { Dusun } \\
\text { Gondangm } \\
\text { anis }\end{array}$ & $\begin{array}{c}\text { Dusun } \\
\text { Prayungan }\end{array}$ & $\begin{array}{c}\text { Dusun } \\
\text { Gondanglegi }\end{array}$ \\
\hline 1. & $\begin{array}{l}\text { Jumlah } \\
\text { Petani }\end{array}$ & 278 & 295 & 369 \\
\hline
\end{tabular}




\begin{tabular}{clccc}
\hline 2. & $\begin{array}{l}\text { Jumlah } \\
\text { pohon }\end{array}$ & & & \\
\hline & $(0-20)$ & 96 & 59 & 13 \\
\hline & $(21-40)$ & 2 & 2 & 3 \\
\hline & $(41-60)$ & 1 & 1 & 2 \\
\hline 3 & Produksi & $\begin{array}{c}25 \mathrm{~kg}- \\
1000 \mathrm{~kg}\end{array}$ & $\begin{array}{c}50 \mathrm{~kg}- \\
1000 \mathrm{~kg}\end{array}$ & $50 \mathrm{~kg}-1500$ \\
$\mathrm{~kg}$
\end{tabular}

Budidaya jambu gondangmanis konvensional memberi dampak nyata pada penurunan kandungan bahan organik lahan, sifat fisik, kimia dan biologis lahan yang selanjutnya menurunkan produktifitas lahan, dan akan menurunkan produktifitas produksi tanaman.Tetapi pertanian konvensional yang tidak memerlukan pupuk akan berakibat pada produksi jambu yang organic, dan berdampak nyata terhadap kesehatan, karena tidak mengandung residu yang berbahaya yang tertinggal pada bahan pangan. Peningkatan pendidikan dan pendapatan masyarakat mempengaruhi kesadaran masyarakat akan produk pangan sehat dan meningkatkan permintaan terhadap produk pangan organik. Hal tersebut memberi dampak positif terhadap permintaan produk organik termasuk jambu gondangmanis. (Zalita1, Hastuti2, \& Dwi Listyorini3, 2017)

\section{B. PELAKSAAAN DAN METODE}

Pelaksanaan Pengabdian masyarakat ini di desa Gondangmanis, kec. Bandar Kedungmulyo, Kabupaten Jombang. Pada bulan April - Agustus 2019. Peserta pengabdian yang ikut adalah kelompok petani jambu, pemuda masyarakat desa, yang menjadi Kelompok sadar wisata (pokdarwis), ibu ibu yang akan memproduksi produksi, dan masyarakat desa Gondangmanis, dan petani jambu sejumlah 250 orang.

Metode yang digunakan dalam pengabdian ini adalah tanam perlubang. Metode Sustainable Organik Farming (SOF) untuk budidaya jambu adalah metode pengelolaan tanaman, tanah, air dan hara sehingga tanaman menunjukkan potensi produksi yang optimal. Teknologi SOF diaplikasikan mulai penyemaian, pemupukan, penanaman, pengolahan lahan, pengelolaan air dan pengendalian hama penyakit.

Sedangkan metode Pelaksanaan yang terkait dengan pemberdayaan masyarakat adalah melalui pendampingan wirausaha dan peningkatan produk pasca olahan jambu gondangmanis melalui pembentukan kelembagaan POKDARWIS dan Wisata Petik Jambu Gondangmanis.

\section{HASIL DAN PEMBAHASAN}

\section{A. Program Pendampingan Teknik Budidaya Jambu Gondangmanis}

\section{Pelatihan Teknologi Sustainable Organik Farming (SOF)}

Budidaya Jambu Gondangmanis yang sudah sejak lama ada di Desa Gondangmanis, meliputi 3 dusun : Dusun Gondangmanis. Gondang legi dan Prayungan, mengalami penurunan kesuburan tanah dan lahan, Oleh karena itu perlu di lakukan konservasi Lahan dengan menggunakan teknologi Teknologi Sustainable Organik Farming (SOF). (Sutanto, 2005)

Pelatihan di hadiri kelompok tani dari dusun Gondangmanis dan Dusun Gondanglegi. Pelatihan menggunakan bahan pencuci pestisida dan meremahkan agregatagregat tanah lapisan atas tanah, sehingga mudah untuk di tanami, akar tanaman mudah berkembang dan mengaktifkan kembali mikro organik tanah.

Prinsip dari implementasi Teknologi Sustainable Organik Farming (SOF)adalah perbaikan lahan dengan menambahkan mineral tanah yang diperlukan oleh tanaman, dan mengaktifkan biologi tanah dan 
mikroorganisme tanah. Sehingga produktivitas dan kesuburan tanah kembali meningkat.

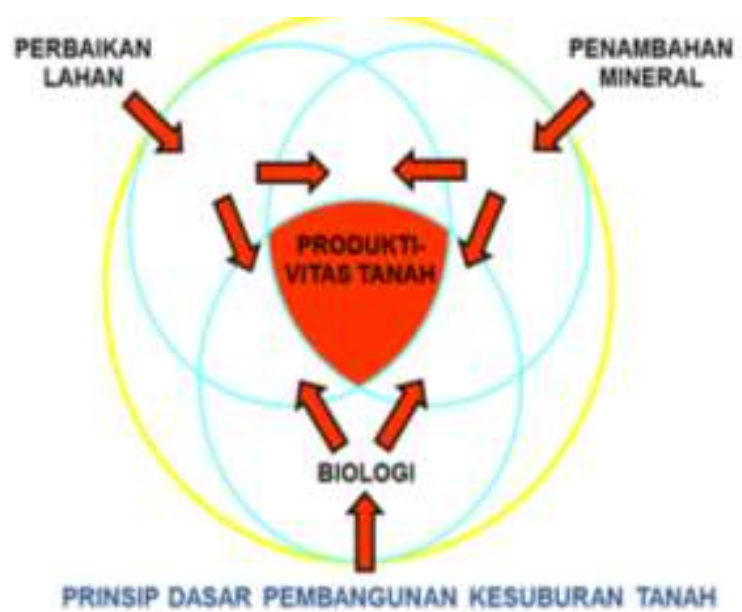

Gambar 1. Prinsip Dasar pembangunan kesuburan Tanah

\section{Pelatihan Pupuk Organik}

Pupuk Organik merupakan pupuk yang sangat baik untuk berlanjutan produksi tanaman.Pupuk organic tersusun dari beberapa unsure pupuk majemuk yang diperoleh dari limbah kotoran ternak dan daun kering, yang difermentasikan kemudian dipeoleh pupuk yang sudah matan prosesnya.Kemudian dilakukan pendinginan dan pupuk siap di gunakan.

Potensi dusun Gondangmanis dan gondanglegi terdapat limbah ternak baik sapi maupun kambing.Kotoran ternaknya belum di manfaatkan dengan baik, oleh karena itu mencemari lingkungan sekitarnya. Limbah ini sebagai bahan baku dari pupuk organic, kemudian di campur dengan limbah daun kering yang dirajang kecil-kecil. Daun yang di pakai adalah daun yang mengandung unsure $\mathrm{P}$ dan $\mathrm{K}$, sehingga sebagai penyumbang unsure $\mathrm{P}$ dan $\mathrm{K}$, sedangkan unsur $\mathrm{N}$ bahan bakunya dari limbah urin ternak atau batang bambu muda. Pelatihan di dusun gondangmanis dan gondanglegi diikuti oleh ketua dan anggota gapoktan Peserta kelihatan antusias mengikutinya.
Pelatihan diadakan di desa Gondangmanis, yang diikuti oleh seluruh anggota kelompok tani (poktan). Pada pelatihan ini, kelompok tani Desa Gondangmanis diajak secara bersama-sama mempraktekkan cara membuat pembuatan pupuk organic yang terdiri dari kotoran hewan (sapi, kambing, ayam). Bahan yang ditambahkan adalah sisa jerami, atau daun kering sisa tanaman, dan suplemen mobilin sebagai staternya.Dengan dosis 1 liter stater untuk bahan 1 ton.Masa pengolahannya 7 hari, dengan pembalikan setiap hari untuk mengeluarkan panasnya.Selama pengolahan bahan di tutup dengan penutup (terpal) atau di tempat yang dingin.Pada hari ke 7, pupuk siap di gunakan di lahan jambu gondangmanis.

\section{B. Pemberdayaan masyarakat produk olahan Jambu Gondangmanis}

Pemberdayaan masyarakat tentang produk olahan jambu gondangmanis adalah menggiatkan masyarakat dalam memproduksi pasca olahan jambu, misalnya tentang minuman sari jambu, selai, syrup, manisan, permen dan es cream. Dengan mengolah sisa jambu yang tidak layak jual, untuk di olah menjadi produk olahan, maka akan menambah nilai jual produk dan dapat meningkatkan ekonomi masyarakat.

Tabel 2. Analisis peluang proses produksi pasca olahan jambu gondangmanis

\begin{tabular}{lccrr}
\hline Produk & $\begin{array}{c}\text { Selai } \\
\text { (cup } \\
\text { @125m } \\
\text { 1) }\end{array}$ & $\begin{array}{c}\text { Sari } \\
\text { minuma } \\
\text { (bottle } \\
\text { @60ml) }\end{array}$ & $\begin{array}{c}\text { Manisa } \\
\text { (pack } \\
\text { @350g } \\
\text { r) }\end{array}$ & $\begin{array}{c}\text { Permen } \\
\text { (pouch } \\
\text { @350g } \\
\text { r) }\end{array}$ \\
\hline Nomer* & 20 & 10 & 20 & 30 \\
\hline Harga & 6.000 & 16.000 & 7.500 & 7.000 \\
\hline $\begin{array}{l}\text { Pendapat } \\
\text { an }\end{array}$ & 120.000 & 160.000 & 150.00 & 210.00 \\
\hline $\begin{array}{l}\text { Biaya } \\
\text { tetap }\end{array}$ & 28.894 & 55.630 & 31.498 & 42.783 \\
\hline
\end{tabular}




\begin{tabular}{lrrrr}
\hline $\begin{array}{l}\text { Biaya } \\
\text { tambaha } \\
\mathrm{n}\end{array}$ & 51.750 & 87.250 & 77.150 & $\begin{array}{r}127.20 \\
0\end{array}$ \\
\hline $\begin{array}{l}\text { Total } \\
\begin{array}{l}\text { Pengelua } \\
\text { ran }\end{array}\end{array}$ & 80.644 & 142.880 & 108.64 & 169.98 \\
& & & 8 & 3 \\
$\begin{array}{l}\text { Keuntun } \\
\text { gan }\end{array}$ & 39.356 & 7.120 & 41.352 & 40.017 \\
\hline HPP & 40.032 & 14.288 & 5.432 & 5.666 \\
\hline R/C & 1,49 & 1,12 & 1,38 & 1,24 \\
\hline \multicolumn{5}{c}{ Source: (Eny Dyah Yuniwati, 2019) } \\
\end{tabular}

\section{Rintisan untuk wisata kampung jambu gondangmanis}

Budidaya jambu gondangmanis yang tersebar di seluruh dusun Desa gondangmanis, maka berpeluang untuk menjadi wisata kampung jambu gondangmanis. Perintisan wisata jambu ini akan di mulai dengan pemasangan gapura di depan jalan masuk ke desa. Tujuannya untuk menyebarkan bahwa di desa ini terdapat budidaya jambu gondangmanis yang sangat manis dan menjadi sentral ungulan kabupaten jombang. Dengan di pasangnya gapura ini masyarakat akan menjadi tahu bahwa pusat budidaya jambu ada di desa ini. Dan akan di kembangkan pula untuk budidaya, pembibitan dan pengolahan hasil jambunya. (Fitriana, 2019).

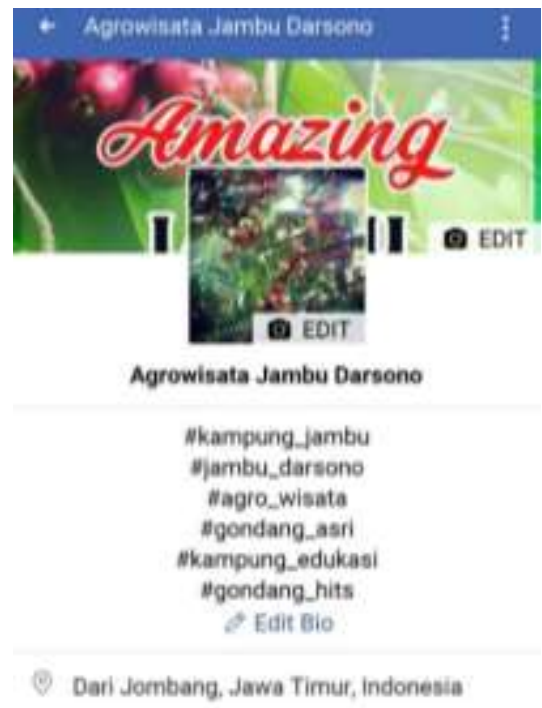

Gambar 2. Pembuatan media sosial untuk memperkenalkan desa wisata Gondangmanis

\section{Penguatan Kelembagaan}

Penguatan kelembagaan ini telah di bentuk dalam bentuk kelompok masyarakat (POKMAS) khusus pengelolaan jambu gondangmanis. Penguatan ini akan menaungi tentang semua keperluan mulai informasi budidaya, pembuatan pupuk, pemelihaaran jambu, pembibitan dan kelembagaan jambu. Bahwa pokmas ini akan menjadikan kampung wisata jambu gondangmanis menjadi terkenal karena sentra produksi jambunya.

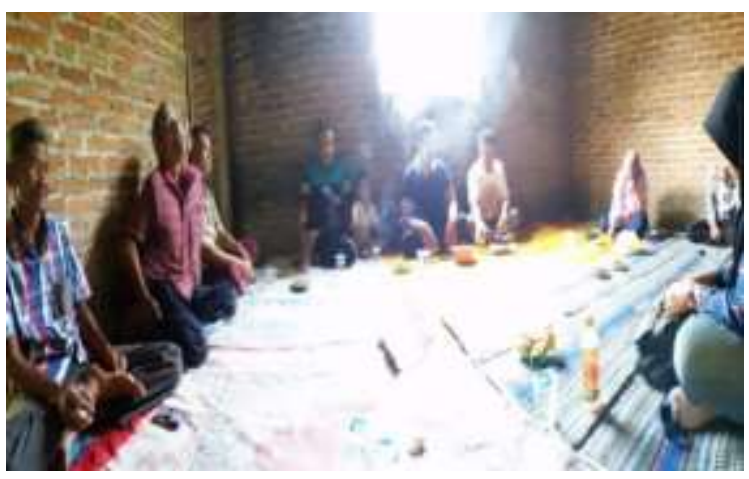

Gambar 3. Penguatan kelembagaan kelompok

\section{Pembentukan POKDARWIS}

POKDARWIS adalah Kelompok Sadar Wisata, kelompok yang akan menjadi inisiasi pengembangan wisata di Gondangmanis. Pokdarwis akan membentuk bidang bidang yang masing masing mempunyai peran, visi dan misi yang sama dalam mengembangkan kampung wisata jambu menjadi lebih baik. Di Gondangmanis Pokdarwis telah terbentuk tgl 7 Desember 2018, dan terdiri dari pemuda pemudi desa yang berpotensi untuk lebih kreatif dalam pengembangan kampung wisata jambu Gondangmanis. Mulai sekarang POKDARWIS akan menyusun Strategi kerja dan programnya. 


\section{PENUTUP}

\section{Simpulan}

Berdasarkan hasil pendampingan di tahun ke 2 ini, implementasi program IbW di Kecamatan Bandar Kedung Mulyo Kabupaten Jombang dapat disimpulkan bahwa telah di lakukan pendampingan, pelatihan dan budidaya produksi jambu Gondangmanis. Partisipasi masyarakat, khususnya yang terlibat dalam kegiatan pengembangan jambu, dan pemanfaatan limbah ternak sangat tinggi. Demikian pula dukungan dari tokoh masyarakat dan perangkat desa serta tingkat kecamatan sangat mendukung. Juga telah di rintis terbentuknya wisata kampung jambu Gondangmanis.Telah terbentuk kelompok Masyarakat jambu Gondangmanis dan Kelompok Sadar Wisata (POKDARWIS). Peran Dinas Pertanian dan Peternakan juga Bappeda Pemerintah Daerah Kabupaten Jombang juga sangat tinggi, karena selama proses persiapan dan koordinasi selalu mendapat perhatian dari pimpinan Pemda, terbukti dengan terbentuknya wisata unggulan jombang.

\section{Saran}

Masih di perlukan pengabdian masyarakat unruk keberlanjutan program pemberdayaan menuju desa wisata yang berdampak terhadap meningkatnya perekonomian masyarakat.

\section{Ucapan Terima Kasih}

Ucapan terimakasih di sampaikan kepada Direktorat Riset dan PengabdianMasyarakat dalam DIPA kontrak dengan DRPM, No Kontrak Nomor SP DIPA-042.06.1.401516/2018 Tanggal 05 Desember 2018.Dan juga kepada semua pihak yang telah berperan serta aktif dalam pelaksanaan kegiatan ini.

\section{E. DAFTAR PUSTAKA}

Fitriana, N. 2019. Implementasi Desain " Name Board ' Desa Wisata Jambu Gondangmanis Kabupaten, 2(1), 44-52.

Suhadi, A. 2019. Strategi Pengembangan Agribisnis Jambu Gondang Manis (Syzygium malances ) di Kabupaten Jombang. Hijau Cendekia, 4(2), 47-59.

Sutanto. 2005. Penerapan pertanian organik. Buku, 253.

Yuniwati, E.D. 2017. Prospek Dan Pengembangan Jambu Gondangmanis Produk Unggulan Kab. Jombang. Prosiding Seminar Abdimas Univ Surabaya, 674-682.

Yuniwati, E.D. 2017. Land Husbandry: The Role Of Biochar As A Soil Enhancer In Cassava Cropping System.

International Journal of Agriculture and Environmental Research, 03(05), 3727-3735.

Yuniwati, E. D. 2019. Analysis of Village Potential and Development of PostHarvest Product To Be the Village of Guava Gondangmanis Tourism. Atlantis Press, 349 (Iccd), 187-190.

Zalita1, H. R., Hastuti2, U. S., \& Listyorini, D. 2017. Survei Kebutuhan Masyarakat Pengrajin Olahan Buah Di Kabupaten Jombang Tentang Pembuatan Nata Dari Jambu Darsono Sebagai Dasar Pengembangan Media Pembelajaran Booklet. In prosiding seminar nasional iii tahun 2017 (pp. 130-132). 